Suska Journal of Mathematics Education

Vol.2, No. 1, 2016, Hal. $31-40$

\title{
Matematika Rekreasi melalui Permainan Kartu
}

\author{
Benny Yong \\ Program Studi Matematika, Universitas Katolik Parahyangan \\ Email: benny_y@unpar.ac.id \\ *Submitted : 01-02-2016*Accepted : 19-03-2016
}

\begin{abstract}
ABSTRAK. Pembelajaran Matematika dapat dibuat lebih menarik melalui sebuah permainan, salah satunya melalui permainan kartu. Pada artikel ini, akan disajikan mengenai sebuah permainan kartu yang dimainkan oleh dua orang dengan aturan tertentu. Hal yang menantang dalam suatu permainan adalah ketika kita dapat memastikan bahwa seseorang dapat memenangkan permainan itu. Secara matematis dengan menggunakan konsep teori bilangan, dapat dipastikan pemenang dari permainan kartu ini.

Kata kunci : permainan, kartu, kongruensi
\end{abstract}

\section{PENDAHULUAN}

Matematika adalah ilmu dasar yang melandasi banyak cabang ilmu pengetahuan lainnya. Sebagai ilmu dasar, pembelajaran matematika di tingkat dasar, menengah, dan atas seringkali merupakan pembelajaran yang abstrak dan proses tidak mengarah kepada pembelajaran pemecahan masalah (problem solving) sehingga kemampuan berpikir kritis, logis, dan analitis dari seseorang yang mempelajari matematika kurang tergali secara baik. Matematika dapat dibuat menjadi suatu rekreasi melalui berbagai macam permainan. Tanpa mengurangi pemahaman akan konsep dasar matematika, pembelajaran matematika akan lebih menarik dipelajari melalui permainan ini. Proses pemecahan masalah dalam pembelajaran matematika melalui permainan ini dapat meningkatkan kemampuan siswa dalam berpikir kritis, logis, dan analitis.

Berbagai macam permainan yang bisa dikaitkan dengan matematika antara lain: permainan dadu, koin, kartu, catur, kelereng, dan lain sebagainya. Banyak dari 
permainan-permainan ini yang dapat dibuat sebagai permainan sulap. Ada juga beberapa permainan yang membutuhkan lebih dari satu pemain dimana dengan kondisi dan aturan tertentu dapat ditentukan seorang pemenang dalam permainan tersebut.

Konsep teori bilangan mulai diperkenalkan lebih jauh sejak seseorang mempelajari matematika di tingkat sekolah dasar. Beberapa permainan matematika membutuhkan konsep teori bilangan yang kompleks dan cukup rumit. Dengan menggunakan konsep teori bilangan ini, kita dapat menyelesaikan beberapa masalah dalam permainan matematika.

Penelitian ini berawal dari permasalahan yang diambil dari soal Olimpiade Matematika Internasional (IMO) tahun 2009 soal kombinatorik C1 (IMO, 2009). Pada artikel ini, permasalahan dibuat lebih umum dan disajikan bukti untuk kebenaran dari klaim yang dibuat. Tujuan penelitian ini adalah untuk menentukan siapa pemenang dari permainan kartu ini sebelum permainan dimulai dengan kondisi dan aturan yang telah ditetapkan sebelumnya.

Dibawah ini disajikan aturan dari permainan ini dan suatu ilustrasi permainan yang dilakukan oleh dua pemain. Gambar-gambar pada sub bagian ilustrasi permainan merupakan hasil dari ouput program yang juga merupakan bagian pekerjaan penelitian.

\section{ATURAN DAN ILUSTRASI PERMAINAN Aturan Permainan}

Berikut ini adalah aturan permainan dalam permainan kartu ini:

1. Permainan dimainkan oleh dua orang

2. Susun kartu-kartu pada $k$ baris $n$ kolom

3. Tentukan banyaknya kartu yang dibalik pada setiap operasi

4. Operasi dilakukan dengan cara memilih sebuah kartu kemudian membalik kartukartu dari kartu yang dipilih ke sebelah kanan sebanyak yang sudah ditentukan.

5. Operasi hanya boleh mulai dilakukan dari kartu dalam posisi terbuka dan kartu yang dibalik dari posisi kartu yang dipilih berjalan ke kanan harus mencukupi banyaknya kartu yang sudah ditentukan pada aturan nomor 3 .

6. Pemain yang kalah adalah pemain yang tidak dapat melakukan operasi pada permainan ini.

\section{Ilustrasi Permainan}

Misalkan ada 15 buah kartu disusun ke dalam 3 baris dan 5 kolom, semua kartu awalnya dalam keadaan terbuka. Ada dua orang pemain yang bergiliran mengoperasikan kartu-kartu tersebut. Banyaknya kartu yang dibalik pada setiap operasi adalah 2 buah kartu. 


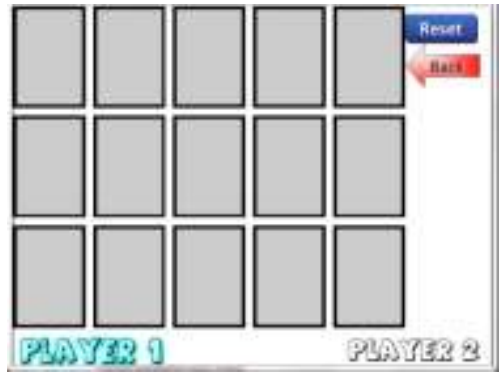

Gambar 1. Kondisi ke-15 Kartu pada Mulanya

Misalkan pemain pertama memilih kartu pada baris 1 kolom 2. Kartu yang dipilih tersebut dan satu kartu sesudahnya menjadi posisi tertutup.

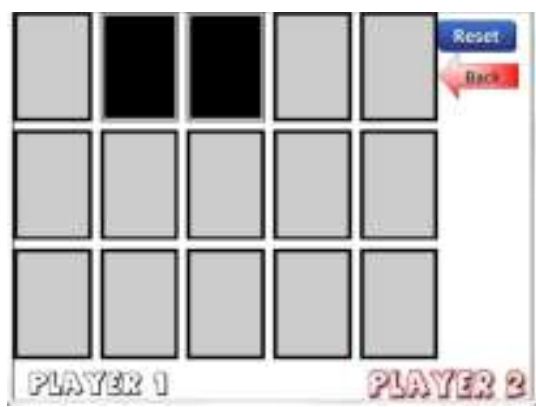

Gambar 2. Langkah Pertama Pemain Pertama

Pemain kedua memilih kartu pada baris 2 kolom 1 sehingga kartu yang dipilih tersebut dan satu kartu sesudahnya menjadi posisi tertutup.

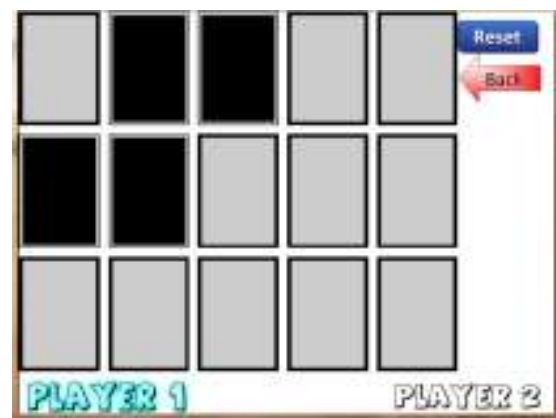

Gambar 3. Langkah Pertama Pemain Kedua

Pemain pertama memilih kartu pada baris 1 kolom 1 sehingga kartu yang dipilih tersebut menjadi posisi tertutup sedangkan satu kartu sesudahnya menjadi posisi terbuka karena sebelumnya tertutup. 


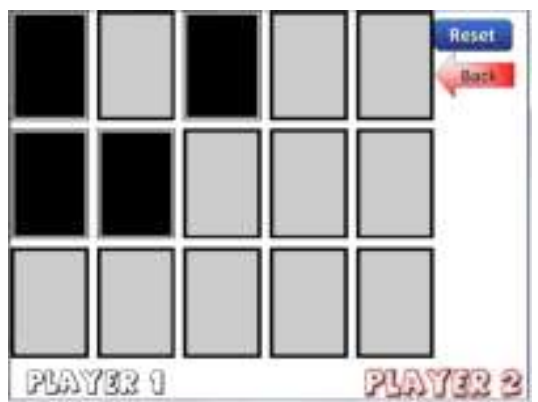

Gambar 4. Langkah Kedua Pemain Pertama

Pemain kedua memilih kartu pada baris 3 kolom 3 sehingga kartu yang dipilih tersebut dan kartu sesudahnya menjadi posisi tertutup.

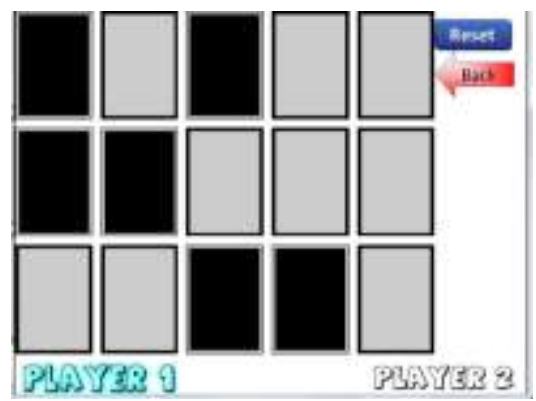

Gambar 5. Langkah Kedua Pemain Kedua

Pemain pertama memilih kartu pada baris 1 kolom 2 sehingga kartu yang dipilih tersebut menjadi tertutup dan satu kartu sesudahnya menjadi terbuka karena sebelumnya tertutup.

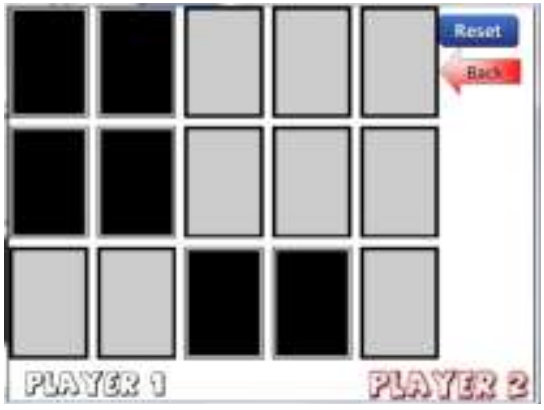

Gambar 6. Langkah Ketiga Pemain Pertama

Pemain kedua memilih kartu pada baris 1 kolom 3 sehingga kartu yang dipilih tersebut dan kartu sesudahnya menjadi posisi tertutup. 


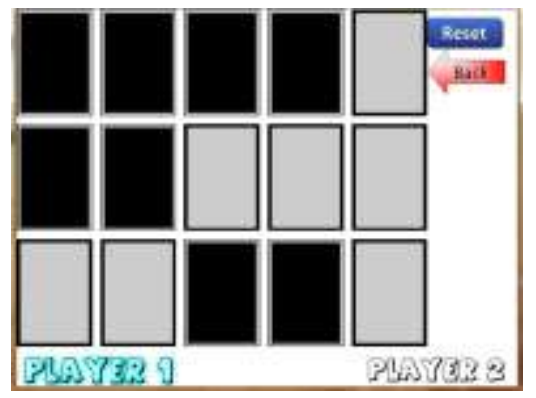

Gambar 7. Langkah Ketiga Pemain Kedua

Pemain pertama memilih kartu pada baris 3 kolom 1 sehingga kartu yang dipilih tersebut dan kartu sesudahnya menjadi posisi tertutup.

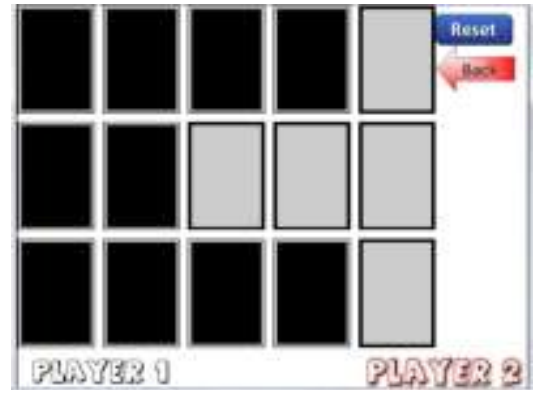

Gambar 8. Langkah keempat pemain pertama

Pemain kedua memilih kartu pada baris 2 kolom 2 sehingga kartu yang dipilih tersebut dan kartu sesudahnya menjadi posisi tertutup.

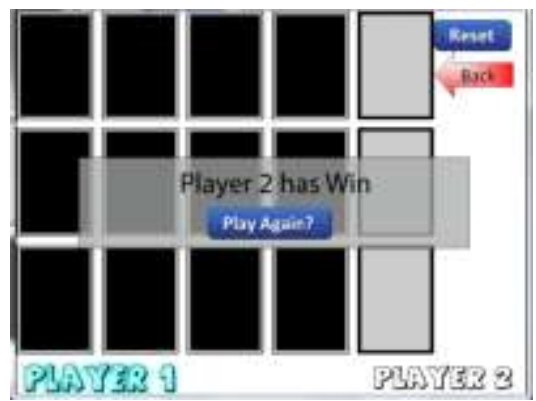

Gambar 9: Langkah keempat permain kedua

Pemain pertama tidak dapat mengoperasikan lagi kartu-kartu tersebut sehingga pemenangnya adalah pemain kedua.

\section{HASIL PENELITIAN DAN PEMBAHASAN}

Misalkan ada $k$ baris. Pada setiap baris ada $n$ kartu dimana semua kartu terbuka. Operasi ke- $i, i=1,2,3, \ldots,(n-m+1)$ pada baris ke- $j, j=1,2,3, \ldots, k$ 
adalah membalikkan $m$ kartu berurutan dimulai dari posisi ke- $i$ dan pada baris ke- $j$, dengan $m \leq n$ dan kartu ke- $i$ adalah kartu dalam posisi terbuka. Akan dibuktikan jika $n, m, k$ diberikan maka dapat ditentukan siapa pemenangnya sebelum permainan dimulai, yaitu:

1. Jika $n \equiv m, m+1, m+2, \ldots, 2 m-1 \bmod 2 m$, dengan $k$ genap atau $n \equiv 0,1,2 \ldots m-1 \bmod 2 m$, maka permainan berakhir dengan orang kedua sebagai pemenang.

2. Jika $n \equiv m, m+1, m+2, \ldots, 2 m-1 \bmod 2 m$, dengan $k$ ganjil, maka pemenangnya adalah orang pertama.

Pertama, akan dibuktikan suatu baris tidak bisa dioperasikan lagi jika dan hanya jika kartu yang pada baris tersebut berposisi $1 \bmod m$ dan bisa dioperasikan, dioperasikan sebanyak ganjil kali dan sisa kartu lainnya dioperasikan sebanyak genap kali.

$(\Leftarrow)$ Jika kartu yang pada baris tersebut berposisi $1 \bmod m$ dan bisa dioperasikan, dioperasikan sebanyak ganjil kali dan sisa kartu lainnya dioperasikan sebanyak genap kali., maka jelas baris itu tidak bisa dioperasikan lagi.

Perhatikan, jika sebuah kartu dioperasikan sebanyak genap kali maka sebenarnya operasi itu tidak mengubah sisi kartu sedangkan jika kartu dioperasikan sebanyak ganjil kali maka operasi tersebut akan mengubah seluruh sisi kartu yang terkena operasi itu. Oleh karena jika dioperasikan sebanyak genap kali tidak mengubah sisi kartu, maka operasi itu bisa diabaikan. Tanpa mengurangi keumuman, kita bisa meniadakan operasi yang dilakukan pada kartu selain $1 \mathrm{mod} m$. Karena operasi yang dilakukan hanya pada kartu di posisi $1 \bmod m$ dan itu mengubah semua sisi kartu yang terkena operasi itu, maka jelas seluruh kartu yang bisa dioperasikan semua sudah dalam keadaan tertutup sehingga tidak ada kartu yang bisa dioperasikan lagi.

$(\Rightarrow)$ Sekarang akan dibuktikan jika baris itu tidak bisa dioperasikan lagi, maka pada baris tersebut pasti kartu yang berposisi $1 \bmod m$ dan bisa dioperasikan, sudah dioperasikan sebanyak ganjil kali dan kartu sisanya sudah dioperasikan sebanyak genap kali. Pernyataan ini ekivalen dengan pernyataan jika pada baris tersebut kartu yang berposisi $1 \bmod m$ dan bisa dioperasikan, ada kartu yang dioperasikan sebanyak genap kali atau ada kartu selain kartu di atas dioperasikan sebanyak ganjil kali, maka baris itu bisa dioperasikan lagi.

a. Ada kartu yang berposisi pada $1 \bmod m$ dan bisa dioperasikan, dioperasikan sebanyak genap kali dan semua kartu yang pada posisi selain 1 mod $m$ dioperasikan sebanyak genap kali, maka baris tersebut masih bisa dioperasikan lagi. Misalkan salah satu kartu yang berada pada posisi 1 mod $m$ yang dioperasikan sebanyak genap kali, kita namakan kartu A. Perhatikan bahwa operasi yang dilakukan sebanyak genap kali bisa diabaikan maka kartu A pasti akan terbuka karena operasi yang dilakukan 
sebanyak genap kali tidak mengubah sisi kartu. Karena operasi yang berpengaruh hanya operasi yang dilakukan sebanyak ganjil kali dan operasi yang dilakukan sebanyak ganjil kali hanya dilakukan di kartu di posisi 1 mod $m$, maka kartu A jelas dalam posisi terbuka. Jadi, jelas pada baris itu masih bisa dioperasikan lagi.

b. Semua kartu yang berposisi pada $1 \bmod m$ dan bisa dioperasikan, dioperasikan sebanyak ganjil kali dan ada kartu yang pada posisi selain 1 mod $m$ yang dioperasikan sebanyak ganjil kali, maka baris tersebut masih bisa dioperasikan lagi. Misalkan kartu yang berada pada posisi selain $1 \bmod m$ dan dioperasikan sebanyak ganjil kali yang paling kiri dinamakan kartu A. Perhatikan, jika kartu yang berposisi 1 mod $m$ dan berada di sebelah kiri kartu A telah dioperasikan sebanyak ganjil kali dan sisa kartu di sebelah kiri kartu A telah dioperasikan sebanyak genap kali maka seluruh kartu yang di sebelah kiri kartu A sudah dalam posisi tertutup. Perhatikan juga karena kartu A dioperasikan sebanyak ganjil kali maka kartu A terbuka dan karena kartu A dioperasikan sebanyak ganjil kali maka kartu A bisa dioperasikan. Perhatikan jika baris tersebut selesai tapi kartu A dioperasikan sebanyak ganjil kali, maka ia dalam posisi terbuka dan masih bisa dioperasikan lagi sehingga baris tersebut masih bisa dioperasikan lagi.

c. Ada kartu yang berposisi pada $1 \bmod m$ dan bisa dioperasikan, dioperasikan sebanyak genap kali dan ada kartu yang pada posisi selain 1 mod $m$ ada yang dioperasikan sebanyak ganjil kali, maka baris tersebut masih bisa dioperasikan lagi. Misalkan, kartu yang paling kiri dari kartu yang memenuhi salah satu dari kondisi di atas dinamakan kartu A.

Jika kartu A berada pada posisi :

1) $1 \bmod m$ : sama seperti kasus a, perhatikan bahwa operasi yang dilakukan sebanyak genap kali bisa diabaikan maka kartu A pasti akan terbuka karena operasi yang dilakukan sebanyak genap kali tidak mengubah sisi kartu. Karena operasi yang berpengaruh hanya operasi yang dilakukan sebanyak ganjil kali dan operasi yang dilakukan sebanyak ganjil kali hanya dilakukan di kartu di posisi $1 \bmod m$, maka kartu A jelas dalam posisi terbuka. Jadi, jelas pada baris itu masih bisa dioperasikan lagi.

2) Selain $1 \bmod m$ : sama seperti kasus $b$, perhatikan, jika kartu yang berposisi $1 \bmod m$ dan berada di sebelah kiri kartu A telah dioperasikan sebanyak ganjil kali dan sisa kartu di sebelah kiri kartu A telah dioperasikan sebanyak genap kali maka seluruh kartu yang di sebelah kiri kartu A sudah dalam posisi tertutup. Perhatikan juga karena kartu A dioperasikan sebanyak ganjil kali maka kartu A terbuka dan karena kartu A dioperasikan sebanyak ganjil kali maka kartu A bisa dioperasikan. Perhatikan jika baris tersebut selesai tapi 
kartu A dioperasikan sebanyak ganjil kali, maka ia dalam posisi terbuka dan masih bisa dioperasikan lagi sehingga baris tersebut masih bisa dioperasikan lagi.

Karena kedua kasus ternyata tidak memungkinkan maka jika ada baris yang sudah tidak bisa dioperasikan lagi dengan ada kartu yang berposisi pada $1 \bmod m$ dan bisa dioperasikan, dioperasikan sebanyak genap kali dan ada kartu yang pada posisi selain $1 \mathrm{mod} m$ ada yang dioperasikan sebanyak ganjil kali, itu tidaklah mungkin.

Dari kasus a, b, dan c, kita bisa menyimpulkan bahwa jika suatu baris itu tidak bisa di operasikan lagi, maka pada baris tersebut pasti kartu yang berposisi $1 \mathrm{mod} \mathrm{m}$ dan bisa di operasikan, sudah dioperasikan sebanyak ganjil kali dan sisanya sudah sebanyak genap kali.

Jadi, suatu akan baris akan selesai atau tidak bisa dioperasikan lagi jika dan hanya jika kartu yang pada baris tersebut yang berposisi $1 \bmod m$ dan bisa dioperasikan, dioperasikan sebanyak ganjil kali dan sisanya sebanyak genap kali.

Kedua, akan dibuktikan jika dalam suatu baris dengan banyaknya kartu $n$, dengan $n \bmod 2 m$ berada di range $[0, m-1]$, maka jika baris tersebut tidak bisa dioperasikan lagi, maka operasi pada baris tersebut telah dilakukan sebanyak genap kali. Sedangkan jika $n \bmod 2 m$ berada di range $[m, 2 m-1]$, dan baris tersebut tidak bisa dioperasikan lagi, maka operasi pada baris tersebut telah dilakukan sebanyak ganjil kali.

Jika

a. $n \equiv 0,1,2 \ldots m-1 \bmod 2 m$.

Perhatikan, dari banyaknya $n$ kartu tersebut pasti ada genap kartu yang berada di posisi $1 \bmod m$ dan bisa dioperasikan. Dari pembuktian diatas, kita tahu permainan berakhir jika dan hanya jika kartu yang pada baris tersebut berposisi $1 \mathrm{mod} m$ dan bisa dioperasikan, dioperasikan sebanyak ganjil kali dan sisa kartu lainnya dioperasikan sebanyak genap kali. Karena banyaknya kartu $1 \bmod m$ yang bisa dioperasikan sebanyak genap kali dan kartu yang selain itu juga dioperasikan sebanyak genap kali. Maka jika permainan tersebut berakhir, pasti juga telah dilakukan operasi sebanyak genap kali, karena jumlah 2 bilangan genap selalu genap.

b. $n \equiv m, m+1, m+2, \ldots, 2 m-1 \bmod 2 m$.

Perhatikan, dari banyaknya $n$ kartu tersebut pasti ada ganjil kartu yang berada di posisi $1 \mathrm{mod} m$ dan bisa dioperasikan. Dari pembuktian diatas, kita tahu permainan berakhir jika dan hanya jika kartu yang pada baris tersebut berposisi $1 \mathrm{mod} m$ dan bisa dioperasikan, dioperasikan sebanyak ganjil kali dan sisa kartu lainnya dioperasikan sebanyak genap kali. Karena banyaknya kartu $1 \bmod m$ yang bisa dioperasikan sebanyak ganjil kali dan kartu yang selain itu dioperasikan sebanyak genap kali. Maka jika 
permainan tersebut berakhir, pasti juga telah dilakukan operasi sebanyak ganjil kali, karena penjumlahan 2 bilangan yang berbeda paritas selalu ganjil.

Maka jika dalam suatu baris dengan banyaknya kartu $n$, dengan $n \bmod 2 m$ berada di range $[0, m-1]$, maka jika baris tersebut tidak bisa dioperasikan lagi, maka operasi pada baris tersebut telah dilakukan sebanyak genap kali. Sedangkan jika $n \bmod 2 m$ berada di range $[m, 2 m-1]$, dan baris tersebut tidak bisa dioperasikan lagi, maka operasi pada baris tersebut telah dilakukan sebanyak ganjil kali.

Ketiga, akan dibuktikan

a. Jika $n \equiv m, m+1, m+2, \ldots, 2 m-1 \bmod 2 m$, dengan $k$ genap atau $n \equiv 0,1,2 \ldots m-1 \bmod 2 m$, maka permainan berakhir dengan orang kedua sebagai pemenang.

b. Jika $n \equiv m, m+1, m+2, \ldots, 2 m-1 \bmod 2 m$, dengan $k$ ganjil, maka pemenangnya adalah orang pertama.

Perhatikan, jika

a. $n \equiv m, m+1, m+2, \ldots, 2 m-1 \bmod 2 m$, dengan $k$ genap.

Perhatikan bahwa jika suatu baris akan tidak bisa dioperasikan lagi, maka di baris tersebut pasti telah dilakukan operasi sebanyak ganjil kali. Karena banyaknya baris ada genap maka jika permainan itu berakhir atau tidak ada operasi yang bisa dilakukan dipermainan tersebut maka pasti di permainan tersebut telah dilakukan operasi sebanyak genap kali, karena perkalian 2 bilangan yang berbeda paritas selalu genap. Sehingga, dalam permainan ini pemenangnya adalah pemain kedua.

b. $n \equiv m, m+1, m+2, \ldots, 2 m-1 \bmod 2 m$, dengan $k$ ganjil.

Perhatikan bahwa jika suatu baris akan tidak bisa dioperasikan lagi, maka di baris tersebut pasti telah dilakukan operasi sebanyak ganjil kali. Karena banyaknya baris ada ganjil maka jika permainan itu berakhir atau tidak ada operasi yang bisa dilakukan dipermainan tersebut maka pasti di permainan tersebut telah dilakukan operasi sebanyak ganjil kali, karena perkalian 2 bilangan ganjil selalu ganjil. Sehingga, dalam permainan ini pemenangnya adalah pemain pertama.

c. $n \equiv 0,1,2 \ldots m-1 \bmod 2 m$, dengan $k$ genap.

Perhatikan bahwa jika suatu baris akan tidak bisa dioperasikan lagi, maka di baris tersebut pasti telah dilakukan operasi sebanyak ganjil kali. Karena banyaknya baris ada genap maka jika permainan itu berakhir atau tidak ada operasi yang bisa dilakukan dipermainan tersebut maka pasti di permainan tersebut telah dilakukan operasi sebanyak genap kali , karena perkalian 2 bilangan genap selalu genap. Sehingga, dalam permainan ini pemenangnya adalah pemain kedua. 
d. $n \equiv 0,1,2 \ldots m-1 \bmod 2 m$, dengan $k$ ganjil.

Perhatikan bahwa jika suatu baris akan tidak bisa dioperasikan lagi, maka di baris tersebut pasti telah dilakukan operasi sebanyak ganjil kali. Karena banyaknya baris ada ganjil maka jika permainan itu berakhir atau tidak ada operasi yang bisa dilakukan dipermainan tersebut maka pasti di permainan tersebut telah dilakukan operasi sebanyak genap kali, karena perkalian 2 bilangan yang berbeda paritas selalu genap. Sehingga, dalam permainan ini pemenangnya adalah pemain kedua.

\section{PENUTUP}

\section{Kesimpulan} berikut:

Dari hasil pembahasan yang telah dilakukan, diperoleh kesimpulan sebagai

1. Jika $n \equiv m, m+1, m+2, \ldots, 2 m-1 \bmod 2 m$, dengan $\mathrm{k}$ genap atau $n \equiv 0,1,2 \ldots m-1 \bmod 2 m$, maka permainan berakhir dengan orang kedua sebagai pemenang.

2. Jika $n \equiv m, m+1, m+2, \ldots, 2 m-1 \bmod 2 m$, dengan $\mathrm{k}$ ganjil, maka pemenangnya adalah orang pertama.

\section{Saran}

Untuk penelitian selanjutnya, permainan ini dapat dikembangkan dengan mengubah aturan permainan, antara lain:

1. Banyaknya kartu pada setiap baris jumlah dibuat berbeda-beda.

2. Operasi pada kartu dilakukan tidak hanya pada suatu baris, tetapi juga dapat dilakukan pada suatu kolom.

\section{DAFTAR PUSTAKA}

Andreescu, T., and Andrica, D. (2009). Number Theory: Structures, Examples, and Problems. Swiss: Birkhauser.

Andreescu, T., \& Feng, Z. (2004). A Path to Combinatorics for Undergraduates: Counting Strategies. Swiss: Birkhauser.

IMO Official. (2009). IMO Shortlist 2009 from The Book “The IMO Compendium". [Online]. Tersedia: http://www.imo-official.org/problems/IMO2009SL.pdf. [20 Juni 2013]. 